Check for updates

Cite this: RSC Adv., 2017, 7, 24878

\section{Antagonistic effect of selenium on lead-induced inflammatory injury through inhibiting the nuclear factor- $\kappa B$ signaling pathway and stimulating selenoproteins in chicken hearts}

\begin{abstract}
Yanyan Liu, $\dagger^{a}$ Xiaoyan Jiao, $\dagger^{b}$ Xiaojie Teng, $\dagger^{c}$ Xianhong Gu$\dagger^{* d}$ and Xiaohua Teng $\left(\mathbb{D} \dagger^{* b}\right.$
Lead $(\mathrm{Pb})$ is a toxic metal and can damage chicken organs. Selenium (Se) is an essential micronutrient and has antagonistic effect on heavy metal toxicity. However, the toxic effect of $\mathrm{Pb}$ on inflammatory factors and selenoproteins, and antagonistic effect of $\mathrm{Se}$ on $\mathrm{Pb}$ toxicity in chicken hearts remain unclear. In the present study, a chicken model to study $\mathrm{Pb}$ and Se was established. Seven-day-old male chickens were randomly divided into the control, the $+\mathrm{Se}$ group, the $+\mathrm{Pb}$ group, and the $\mathrm{Se}+\mathrm{Pb}$ group. The feeding program of $\mathrm{Pb}$ and Se was as follows: lead acetate was added to drinking water and sodium selenite was added to the standard diet. Relative mRNA levels of four inflammatory factors (nuclear factor- $\mathrm{B}$ (NF- $\mathrm{B}$ ), tumor necrosis factor- $\alpha$, cyclooxygenase-2, and prostaglandin $E$ synthases) and 25 selenoproteins (including glutathione peroxidase 1 (Gpx1), Gpx2, Gpx3, and Gpx4, thioredoxin reductase 1 (Txnrd1), Txnrd2, Txnrd3, iodothyronine deiodinase 1 (Dio1), Dio2, Dio3, selenoprotein n1 (Sepn1), selenoprotein K (Selk), Sels, Sepw1, Selt, Selh, Selm, 15 kDa selenoprotein, Seli, Selu, Selpb, Sepp1, Selo, Sepx1, selenophosphate synthetase 2 (SPS2)) were detected on the $30^{\text {th }}, 60^{\text {th }}$, and $90^{\text {th }}$ days in chicken hearts. The results indicated that $\mathrm{Pb}$ poisoning increased mRNA levels of inflammatory factors, decreased mRNA levels of selenoproteins, and caused histological changes in the chicken hearts. Se alleviated $\mathrm{Pb}$-caused all the above changes in the chicken hearts. Our results suggested that Se supplementation alleviated $\mathrm{Pb}$ induced inflammatory injury through inhibiting the NF-KB signaling pathway and stimulating selenoproteins in the chicken hearts.
\end{abstract}

Received 2nd January 2017

Accepted 27th January 2017

DOI: $10.1039 / \mathrm{c} 7 \mathrm{ra00034k}$

rsc.li/rsc-advances

\section{Introduction}

Lead $(\mathrm{Pb})$ is a toxic metal and exists in natural environment. $\mathrm{Pb}$ contaminated fodder and water pose potential risks to humans through the food chain. The concentration of $\mathrm{Pb}$ increased in cattle and sheep living near a Pb-polluted mining area. ${ }^{1} \mathrm{~Pb}$ has a negative influence on the central nervous system, ${ }^{2}$ and the behavior and mental development of children. ${ }^{3} \mathrm{~Pb}$ has adverse effects on animals, such as rat kidneys, ${ }^{4}$ chicken livers, ${ }^{5}$ and cartilage tissue ${ }^{6}$ and $\mathrm{Pb}$ induced cardiovascular toxicity in rats. ${ }^{7}$ A previous study indicated that $\mathrm{Pb}$ exposure activated

${ }^{a}$ College of Veterinary Medicine, Northeast Agricultural University, Harbin 150030, People's Republic of China

${ }^{b}$ College of Animal Science and Technology, Northeast Agricultural University, Harbin 150030, People's Republic of China. E-mail: tengxiaohua@neau.edu.cn; Tel: +86-45155191485

'Grassland Workstation in Heilongjiang Province, Harbin 150067, People's Republic of China

${ }^{d}$ Institute of Animal Science, Chinese Academy of Agricultural Sciences, Beijing 100193, People's Republic of China. Tel: +86-010-62815895

$\dagger$ All authors have read the manuscript and agreed to submit it in its current form for consideration for publication in RSC Advances. cyclooxygenase-2 (COX-2) in rat vascular smooth muscle cells. ${ }^{8}$ Inflammation is a characteristic of the clinical syndrome of heart failure. ${ }^{9}$ Research has investigated the roles of inflammatory markers such as tumor necrosis factor- $\alpha$ (TNF- $\alpha$ ) and

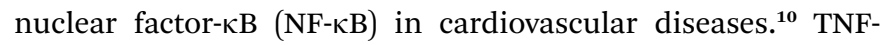
$\alpha$ could serve as a potential bio-marker for coronary heart disease. ${ }^{11} \mathrm{NF}-\kappa \mathrm{B}$ regulates the expression of TNF- $\alpha .{ }^{12}$ Prostaglandin E2 (PGE2) is a principal mediator of inflammation in diseases. ${ }^{13}$ Arachidonic acid is transformed into PGE2 via cyclooxygenase enzymes in cells. ${ }^{14}$ Therefore, NF- $\kappa \mathrm{B}$ signaling pathways are important in heart diseases. A study also found that exposure to cadmium (Cd) increased TNF- $\alpha$ in Wistar rat heart tissues. ${ }^{15}$ However, the mechanism of inflammatory response caused by $\mathrm{Pb}$ is still unclear in chicken hearts. Therefore, we investigated the effect of $\mathrm{Pb}$ on NF- $\mathrm{BB}$ signaling pathway in chicken hearts.

Selenium (Se) is an essential micronutrient and can antagonize different heavy metal toxicities ${ }^{16}$ and hepatocellular carcinoma. ${ }^{17}$ Se plays an important role in maintaining normal cardiovascular function. Many of its physiologic roles are directly attributed to its presence within selenoproteins in the form of the amino acid selenocysteine. ${ }^{18}$ Studies have shown 
that Se deficiency can cause heart damage, such as Keshan disease ${ }^{19}$ and Chagas' disease ${ }^{20}$ However, antagonistic effect of $\mathrm{Se}$ on $\mathrm{Pb}$ toxicity is still unclear in chicken hearts.

Effect of $\mathrm{Pb}$ on mammals and chickens has recently attracted considerable attention. For example, Hao Wang et al. ${ }^{21}$ studied that $\mathrm{Se}$ alleviated $\mathrm{Pb}$-induced increase of relative mRNA expression of inflammation factors and heat shock proteins in chicken livers. However, inflammatory injury induced by $\mathrm{Pb}$ and protective effect of $\mathrm{Se}$ on $\mathrm{Pb}$ poisoning in chicken hearts remain unclear. The aim of the present study was to explore antagonistic effect of dietary Se on inflammatory injury induced by $\mathrm{Pb}$ toxicity through measuring mRNA levels of inflammatory factors and selenoproteins, and to provide theoretical basis of remission effect of Se on heart injury induced by $\mathrm{Pb}$ in chickens.

\section{Materials and methods}

\subsection{Animal model and tissue sample}

One hundred and eighty Hyline male chickens (1 day-old) were acclimated for 7 days and then randomly divided into four groups. The control group was fed basic diet $\left(0.49 \mathrm{mg} \mathrm{kg}^{-1} \mathrm{Se}\right)$ and drinking water. The + Se group was fed sodium selenite $\left(\mathrm{Na}_{2} \mathrm{SeO}_{3}\right.$, analytical reagent grade, Tianjinzhiyuan, Chemical Reagent Co. Ltd., Tianjin, China)-added the basic diet (1 $\mathrm{mg}$ $\mathrm{kg}^{-1} \mathrm{Se}$ ) and drinking water. The $+\mathrm{Pb}$ group was fed lead acetate
$\left(\left(\mathrm{CH}_{3} \mathrm{OO}\right)_{2} \mathrm{~Pb}\right.$, analytical reagent grade, Tianjinzhiyuan Chemical Reagent Co. Ltd., Tianjin, China)-added drinking water (350 $\left.\mathrm{mg} \mathrm{L}^{-1} \mathrm{~Pb}\right)$, according to median lethal dose $\left(\mathrm{LD}_{50}\right)$ for $\mathrm{Pb}$ in chickens ${ }^{22}$ and the need of the chicken experiment in toxicology. ${ }^{23}$ The $\mathrm{Se}+\mathrm{Pb}$ group was fed $\mathrm{Na}_{2} \mathrm{SeO}_{3}$-added the basic diet $\left(1 \mathrm{mg} \mathrm{kg}{ }^{-1} \mathrm{Se}\right)$ and $\left(\mathrm{CH}_{3} \mathrm{OO}\right)_{2} \mathrm{~Pb}$-added drinking water (350 $\mathrm{mg} \mathrm{L}^{-1} \mathrm{~Pb}$ ). The chickens were maintained in the Laboratory Animal Center, College of Veterinary Medicine, Northeast Agricultural University, China. Food and water were provided ad libitum.

On the $30^{\text {th }}, 60^{\text {th }}$, and $90^{\text {th }}$ days of the experiment, fifteen chickens in each group were randomly selected, and euthanasia was performed. Heart tissues were quickly removed, rinsed with ice-cold, sterile deionized water. Each heart was divided into two parts. One part was fixed with 5\% paraformaldehyde for histological observation. Another part was frozen in liquid nitrogen and stored at $-80{ }^{\circ} \mathrm{C}$ until required. All procedures used in this experiment were approved by the Northeast Agricultural University's Institutional Animal Care and Use Committee under the approved protocol number SRM-06.

\subsection{Relative mRNA levels of inflammatory factors and selenoproteins}

2.2.1 Primer synthesis. The primer sequences of inflammatory factors and selenoproteins published in GenBank were

Table 1 Gene special primers used in the quantitative real-time reverse transcription PCR

\begin{tabular}{|c|c|c|c|}
\hline Gene & Serial number & Forward primer $\left(5^{\prime} \rightarrow 3^{\prime}\right)$ & Reverse primer $\left(5^{\prime} \rightarrow 3^{\prime}\right)$ \\
\hline $\mathrm{NF}-\kappa \mathrm{B}$ & NM_205134 & TCAACGCAGGACCTAAAGACAT & GCAGATAGCCAAGTTCAGGATG \\
\hline TNF- $\alpha$ & NM_204267 & GCCCTTCCTGTAACCAGATG & ACACGACAGCCAAGTCAACG \\
\hline PTGEs & NM_001194983 & GTTCCTGTCATTCGCCTTCTAC & CGCATCCTCTGGGTTAGCA \\
\hline $\mathrm{COX}-2$ & NM_001167718 & TGTCCTTTCACTGCTTTCCAT & TTCCATTGCTGTGTTTGAGGT \\
\hline GPx1 & BX935086.2 & ACGGCGCATCTTCCAAAG & TGTTCCCCCAACCATTTCTC \\
\hline GPx2 & NM_001277854.1 & ACGGCACCAACGAGGAGAT & TTCAGGTAGGCGAAGACGG \\
\hline GPx3 & NM_001163232.1 & CCTGCAGTACCTCGAACTGA & CTTCAGTGCAGGGAG GATCT \\
\hline GPx4 & AF498316 & CTTCGTCTGCATCATCACCAA & TCGACGAGCTGAGTGTAATTCAC \\
\hline Dio1 & Y11110.1 & GCGCTATACCACAGGCAGTA & GGTCTTGCAAATGTCACCAC \\
\hline Dio2 & AF125575.1 & ATTTGCTGATCACGCTTCAG & GCTCAGAAACAGCACCATGT \\
\hline Dio3 & Y11273.1 & CTGTGCATTCGCAAGAAGAT & GCCGACTTGAAGAAGTCCAG \\
\hline Txnrd1 & NM_001030762.2 & TACGCCTCTGGGAAATTCGT & CTTGCAAGGCTTGTCCCAGTA \\
\hline Txnrd2 & NM_001122691.1 & GCTCTTAAAGATGCCCAGCACTAC & GAACAGCTTGAGCCATCACAGA \\
\hline Txnrd3 & NM_001122777.1 & CCTGGCAAAACGCTAGTTGTG & CGCACCATTACTGTGACATCTAGAC \\
\hline Sepn1 & NM_001114972.1 & CAGGATCCATGCTGAGTTCCA & GAGAGGACGATGTAACCCGTAAAC \\
\hline Selk & NM_001025441.2 & GAAGAGGGCCTCCAGGAAAT & CAGCCATTGGTGGTGGACTAG \\
\hline Sels & NM_001024734.2 & GCGTCGCCATCTATCTCATCGT & TCTTCTGCCTTCGCTTCTGTTCTT \\
\hline Selw1 & NM_001166327.1 & TGGTGTGGGTCTGCTTTACG & CCAAAGCTGGAAGGTGCAA \\
\hline Selt & NM_001006557.3 & AGGAGTACAT GCGGG TCATCA & GACAGACAGGAAGGATGCTATGTG \\
\hline Selh & BX932816.2 & CATCGAGCACTGCCGTAG & GACACCTCGAAGCTGTTCCT \\
\hline Selm & CR390234.1 & AAGAAGGACCACCCAGACCT & GCTGTCCTGTCTCCCTC ATC \\
\hline Sep15 & NM_001012926.2 & ACTTGGCTTCTCCAGTAACTTGCT & GCCTACAGAATGGATCCAACTGA \\
\hline Seli & XM_426086.1 & TGCCAGCCTCTGAACTGGAT & TGCAAACCCAGACATCACCAT \\
\hline Selu & NM_001193518.1 & GATGCTTTCAGGCTTCTTCC & CTGTCTTCCTGCTCCAATCA \\
\hline Selpb & XM_003641687.1 & AGGCCAACAGTACCATGGAG & GTGGTGAGGATGGAGATGGT \\
\hline Sepp1 & NM_001031609 & CCAAGTGGTCAGCATTCACATC & ATGACGACCACCCTCACGAT \\
\hline Selo & NM_001115017.1 & CCAGCGTTAACCGGAATGAT & ATGCGCCTCCTGGATTTCT \\
\hline Sepx1 & NM_001135558.1 & TGGCAAGTGTGGCAATGG & GAATTTGAGCGAGCTGCTGAAT \\
\hline SPS2 & NM_001187543.1 & CGTTGGGTATCGGAACTGAC & CGTCCACCAGAGGGTAGAAA \\
\hline GADPH & K01458 & AGAACATCATCCCAGCGT & AGCCTTCACTACCCTCTTG \\
\hline
\end{tabular}


showed in Table 1. GAPDH was used as an internal reference gene. The primers were synthesized by Invitrogen Biotechnology Co. Ltd., Shanghai, China.

2.2.2 Total RNA isolation and reverse transcription. The extraction of total RNA was performed using TRIzol reagent according to the manufacturer's instructions (Invitrogen, China). The dried RNA pellets were resuspended in $40 \mu \mathrm{L}$ of diethylpyrocarbonate-treated water. The concentration and purity of the total RNA were determined spectrophotometrically (Healthcare Bio-Sciences AB, Sweden) at 260/280 nm. Reverse transcription (RT) reactions $(60 \mu \mathrm{L})$ contained $6 \mu \mathrm{L}$ of total RNA, $1.5 \mu \mathrm{L}$ of RNase inhibitor, $3 \mu \mathrm{L}$ of dNTP mixture (10 mM each), $3 \mu \mathrm{L}$ of $20 \times$ oligo dT (25), $3 \mu \mathrm{L}$ of golden $\mathrm{M}$ MLV RT, $6 \mu \mathrm{L}$ of $10 \times$ RT buffer, and $37.5 \mu \mathrm{L}$ of RNase free $\mathrm{H}_{2} \mathrm{O}$. The RT procedure carried on three times of water bath heating, at $30^{\circ} \mathrm{C}$ for $15 \mathrm{~min}$, at $55^{\circ} \mathrm{C}$ for $50 \mathrm{~min}$, and at $85{ }^{\circ} \mathrm{C}$ for $10 \mathrm{~min}$. The cDNA was diluted five times with sterile water and stored at $-20{ }^{\circ} \mathrm{C}$ until used.

2.2.3 Quantitative real-time PCR. Quantitative real-time PCR was performed using Light Cycler ${ }^{\circledR} 96$ System according to the manufacturer's instruction (Roche, Switzerland). Reactions were performed in a $10 \mu \mathrm{L}$ reaction mixture containing 5 $\mu \mathrm{L}$ of $2 \times$ SYBR green PCR master mix (Roche, Switzerland), 1 $\mu \mathrm{L}$ of diluted cDNA, $0.3 \mu \mathrm{L}$ of each primer $(10 \mu \mathrm{M})$, and $3.4 \mu \mathrm{L}$ of PCR-grade water. The PCR procedure consisted of heating the reaction mixture to $52{ }^{\circ} \mathrm{C}$ for $2 \mathrm{~min}$ and $95{ }^{\circ} \mathrm{C}$ for $10 \mathrm{~min}$ followed by 40 cycles of $95{ }^{\circ} \mathrm{C}$ for $15 \mathrm{~s}$ and $60^{\circ} \mathrm{C}$ for $1 \mathrm{~min}, 95^{\circ} \mathrm{C}$ for $15 \mathrm{~s}$, and $60{ }^{\circ} \mathrm{C}$ for $20 \mathrm{~s}$. The melting curve analysis showed only one peak for each PCR product. Electrophoresis was performed with the PCR products to verify primer specificity and product purity. A dissociation curve was run for each plate to confirm the production of a single product. The experiment was repeated 3 times for each sample. Relative mRNA abundance was calculated according to the method of Pfaffl. ${ }^{24}$

\subsection{Histological observation}

The tissues were placed in 5\% paraformaldehyde solution. Paraffin-embedded issue block was performed. Each issue block was sliced into $5 \mu \mathrm{m}$-thick sections. The sections were mounted on glass and stained with hematoxylin and eosin. The slides were observed under a light microscope (Eclipse 80i, Nikon, Tokyo, Japan).

\subsection{Statistical analysis}

Statistical analyses of all data were carried out with two-way analysis of variance (ANOVA) using SPSS (version 13; SPSS Inc., Chicago, IL, USA) for Windows. The comparisons for groups were verified by nonparametric as Kruskal-Wallis ANOVA test and Mann-Whitney $U$ test. The data were presented as means \pm standard deviation (bars, $n=5$ ). Statistically significant differences: bars with different uppercase letters within the same group at different time points are significantly different $(P<0.05)$, and bars with different lowercase letters in the different groups at the same time point are significantly different $(P<0.05)$.

\section{Results}

\subsection{NF- $\kappa B$, TNF- $\alpha$, COX-2, and PTGEs mRNA expression}

Relative mRNA expression of inflammatory factors (NF- $\kappa \mathrm{B}$ (Fig. 1a), TNF- $\alpha$ (Fig. 1b), COX-2 (Fig. 1c), and PTGEs (Fig. 1d)) was shown in Fig. 1. All the inflammatory factors in the $+\mathrm{Pb}$ group were significantly higher $(P<0.05)$ than that in the control, $+\mathrm{Se}$, and $\mathrm{Se}+\mathrm{Pb}$ groups. And all the inflammatory factors in the $\mathrm{Se}+\mathrm{Pb}$ group were significantly higher $(P<0.05)$ than those in the control and + Se groups. NF- $\kappa \mathrm{B}, \mathrm{TNF}-\alpha$, and COX-2 increased significantly $(P<0.05)$ with the increase of treatment time in the $+\mathrm{Pb}$ group. PTGEs on the $90^{\text {th }}$ day was significantly higher $(P<0.05)$ than that on the $30^{\text {th }}$ and $60^{\text {th }}$ days
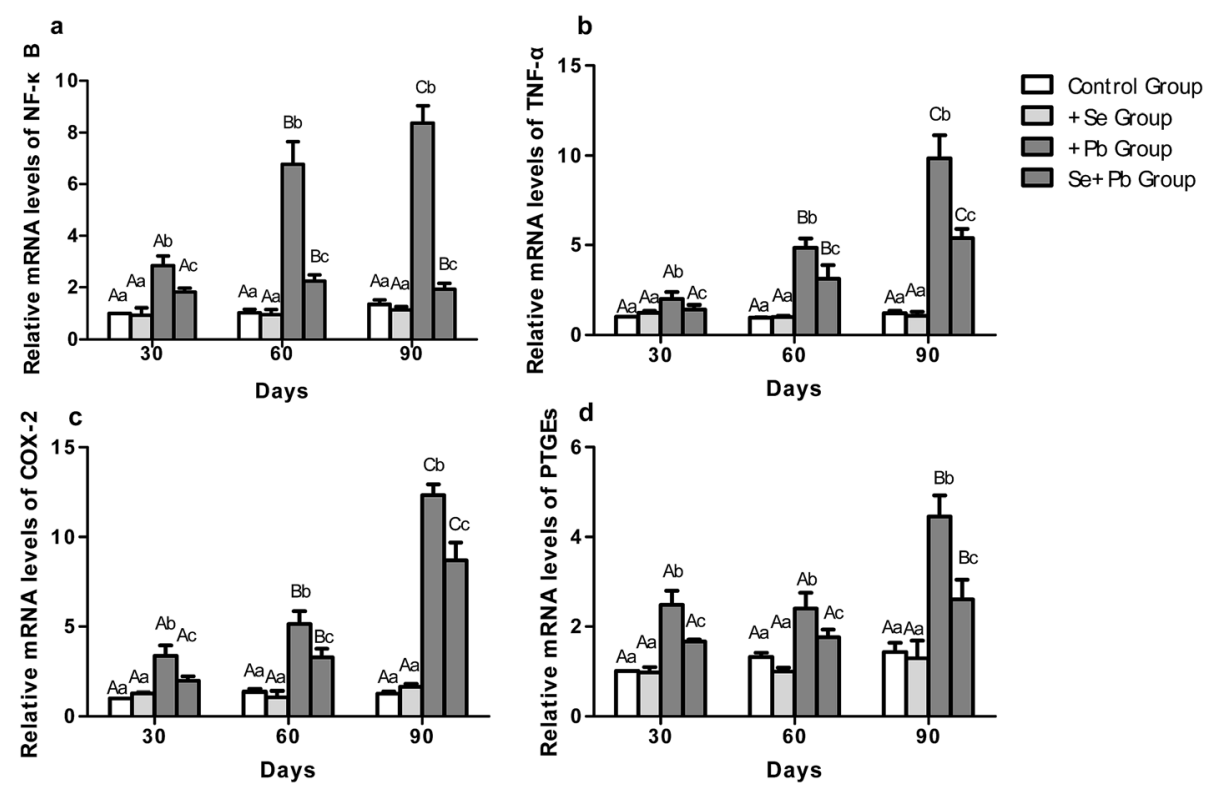

Fig. $1 \mathrm{NF}-\kappa \mathrm{B}, \mathrm{TNF}-\alpha, \mathrm{COX}-2$ and PTGEs mRNA levels in chicken hearts. Fifteen chickens consisted of five replicate pens, with each pen containing three chickens. 
in the $+\mathrm{Pb}$ and $\mathrm{Se}+\mathrm{Pb}$ groups. NF- $\mathrm{B}$ on the $60^{\text {th }}$ and $90^{\text {th }}$ days was significantly higher $(P<0.05)$ than that on the $30^{\text {th }}$ day in the $\mathrm{Se}+\mathrm{Pb}$ group. TNF- $\alpha$ and COX-2 increased significantly $(P<$ $0.05)$ with the increase of treatment time.

\subsection{Gpx1, Gpx2, Gpx3, and Gpx4 mRNA expression}

Glutathione peroxidase 1 (Gpx1), Gpx2, Gpx3, and Gpx4 mRNA expression was shown in Fig. 2. Relative mRNA levels of all the Gpxs in the $+\mathrm{Pb}$ group were significantly decreased $(P<0.05)$ compared with those in the control, $+\mathrm{Se}, \mathrm{Se}+\mathrm{Pb}$ groups except Gpx1 and Gpx4 on the $30^{\text {th }}$ and $60^{\text {th }}$ days, and Gpx3 on the $30^{\text {th }}$ day. All the Gpxs in the $\mathrm{Se}+\mathrm{Pb}$ group were significantly decreased $(P<0.05)$ compared with those in the control and + Se groups except $\mathrm{Gpx} 3$ on the $90^{\text {th }}$ day. In the $+\mathrm{Pb}$ group, Gpx1 on the $60^{\text {th }}$ and $90^{\text {th }}$ days was significantly decreased $(P<0.05)$ compared with that on the $30^{\text {th }}$ day. Gpx2 and Gpx3 decreased significantly $(P<0.05)$ with the increase of treatment time. Gpx4 on the $90^{\text {th }}$ day was significantly increased $(P<0.05)$ compared with that on the $30^{\text {th }}$ and $60^{\text {th }}$ days.

\subsection{Thioredoxin reductases and iodothyronine deiodinases mRNA expression}

Relative mRNA expression of thioredoxin reductases (Txnrds) and iodothyronine deiodinases (Dios) was shown in Fig. 3. Txnrd1, Txnrd2, Txnrd3, Dio1, Dio2, and Dio3 in the $+\mathrm{Pb}$ group were significantly lower $(P<0.05)$ than those in the control, + Se,
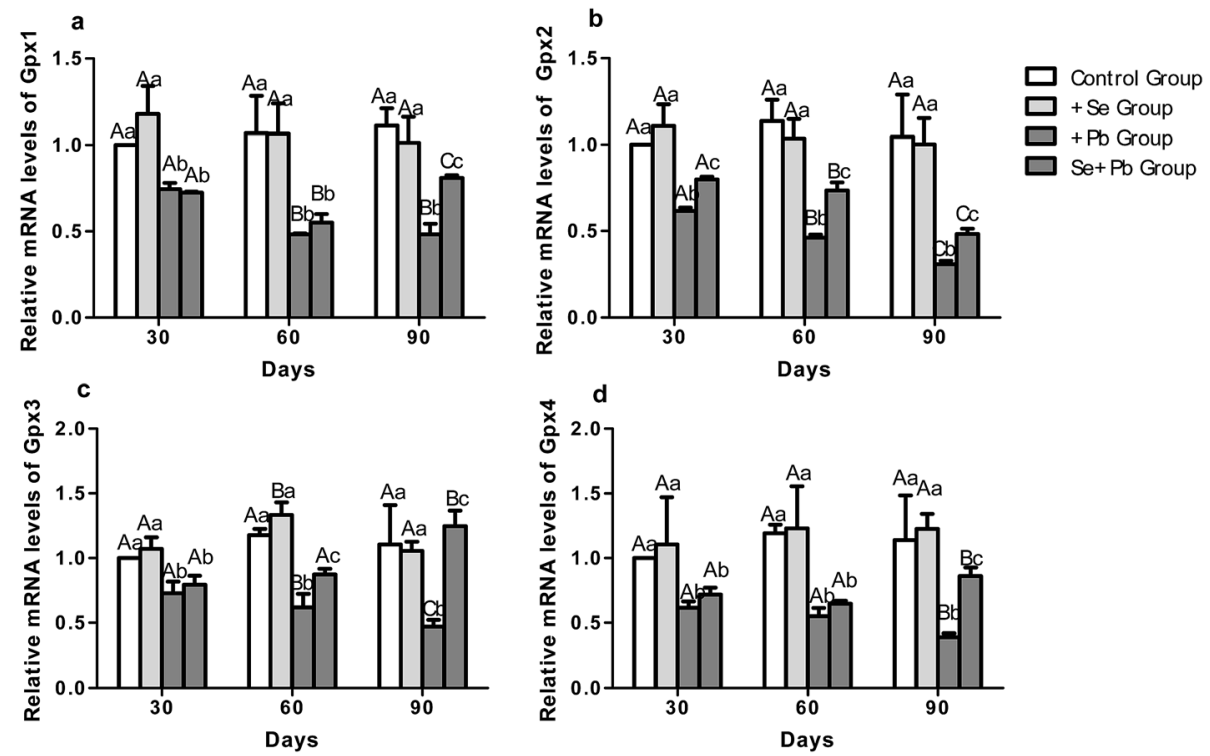

Fig. 2 Gpx1, Gpx2, Gpx3, and Gpx4 mRNA levels in chicken hearts. Fifteen chickens consisted of five replicate pens, with each pen containing three chickens.
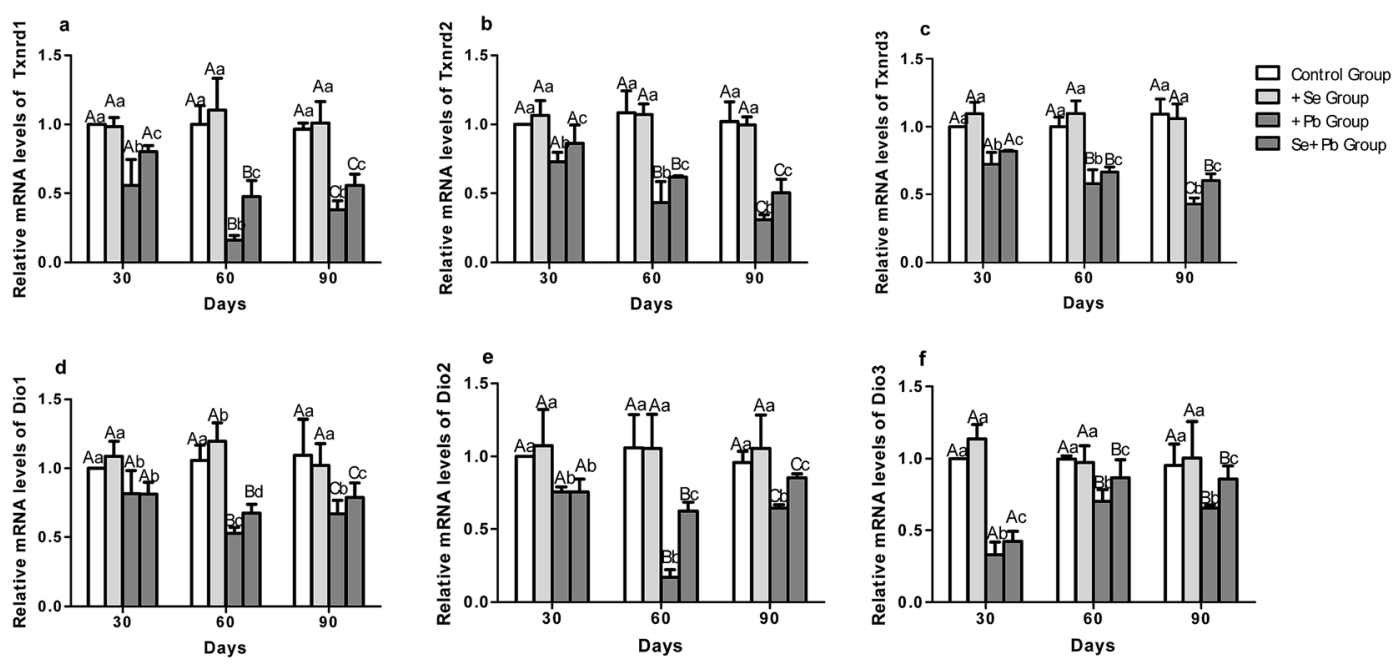

Fig. 3 Txnrds and Dios mRNA levels in chicken hearts. Txnrd1, Txnrd2, Txnrd3, Dio1, Dio2 and Dio3 were showed. Fifteen chickens consisted of five replicate pens, with each pen containing three chickens. 
and $\mathrm{Se}+\mathrm{Pb}$ groups except Dio1 and Dio2 on the $30^{\text {th }}$ day. Txnrds and Dios in the $\mathrm{Se}+\mathrm{Pb}$ group were significantly lower $(P<0.05)$ than those in the control and + Se groups.

\subsection{Relative mRNA expression of 15 selenoproteins}

Relative mRNA expression of 15 selenoproteins was detected. As shown in Fig. 4, selenoprotein $\mathrm{n} 1$ (Sepn1), selenoprotein $\mathrm{K}$ (Selk), Sels, Sepw1, Selt, Selh, Selm, 15 kDa selenoprotein (Sep15), Seli, Selu, Selpb, Sepp1, Selo, Sepx1, selenophosphate synthetase 2 (SPS2) in the $+\mathrm{Pb}$ group were significantly decreased $(P<0.05)$ compared with those in the control, + Se, and $\mathrm{Se}+\mathrm{Pb}$ groups. All the selenoproteins in the $\mathrm{Se}+\mathrm{Pb}$ group were significantly decreased $(P<0.05)$ compared with those in the control and + Se groups.

\subsection{Histological observation}

Histological results were shown in Fig. 5. In the control group on the 90 day, histology of chicken heart tissue displayed normal structure with regular morphology (Fig. 5a). In the $+\mathrm{Pb}$ group on the $30^{\text {th }}$ day (Fig. 5b), there was lightly edema in cardiac muscle cells. In the $+\mathrm{Pb}$ group on the $60^{\text {th }}$ day (Fig. $5 \mathrm{c}$ ), cardiac muscle cells had edema. Muscle fiber pulp had dissolved. Cell hypertrophy and vacuole degeneration were observed. In the $+\mathrm{Pb}$ group on the $90^{\text {th }}$ day (Fig. $5 \mathrm{~d}$ ), cardiac muscle cells occurred focal necrosis and inflammatory cell infiltration. In the $\mathrm{Se}+\mathrm{Pb}$ group (Fig. $5 \mathrm{e}$ ) on the $90^{\text {th }}$ day, some cardiac muscle fibers were slightly disorganized. Some cardiac muscle cells occurred inflammatory cell infiltration.

\section{Discussion}

$\mathrm{Pb}$ can cause inflammatory injury in testicular macrophages of male Swiss albino mice. ${ }^{25}$ Inflammatory processes play critical roles in the treatment of heart failure. ${ }^{26}$ NF- $\kappa \mathrm{B}$ activation could cause cardiomyopathy and heart failure by evoking an excessive inflammatory response in cardiomyocytes. ${ }^{27} \mathrm{NF}-\kappa \mathrm{B}$ regulates
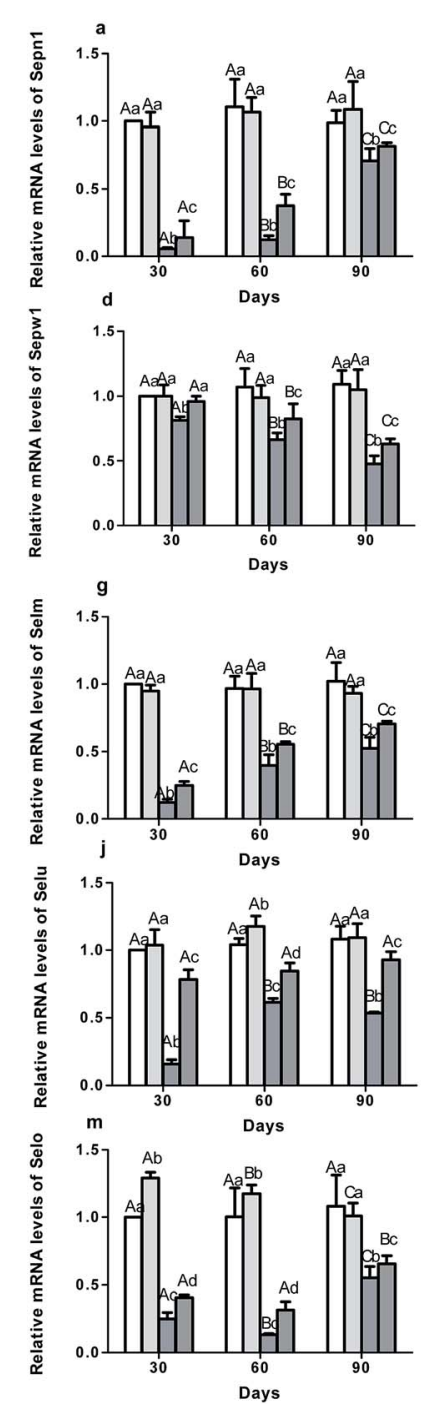
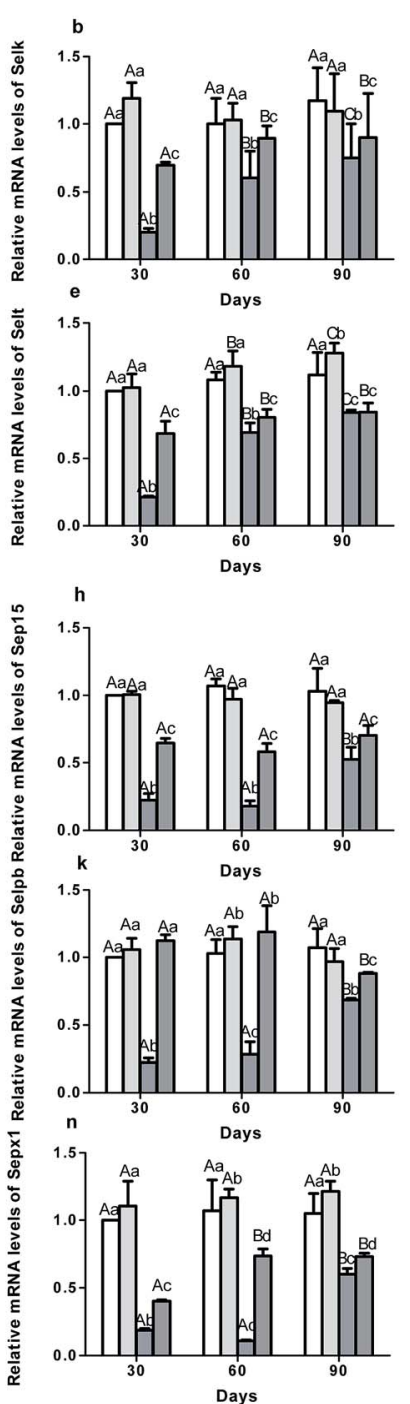

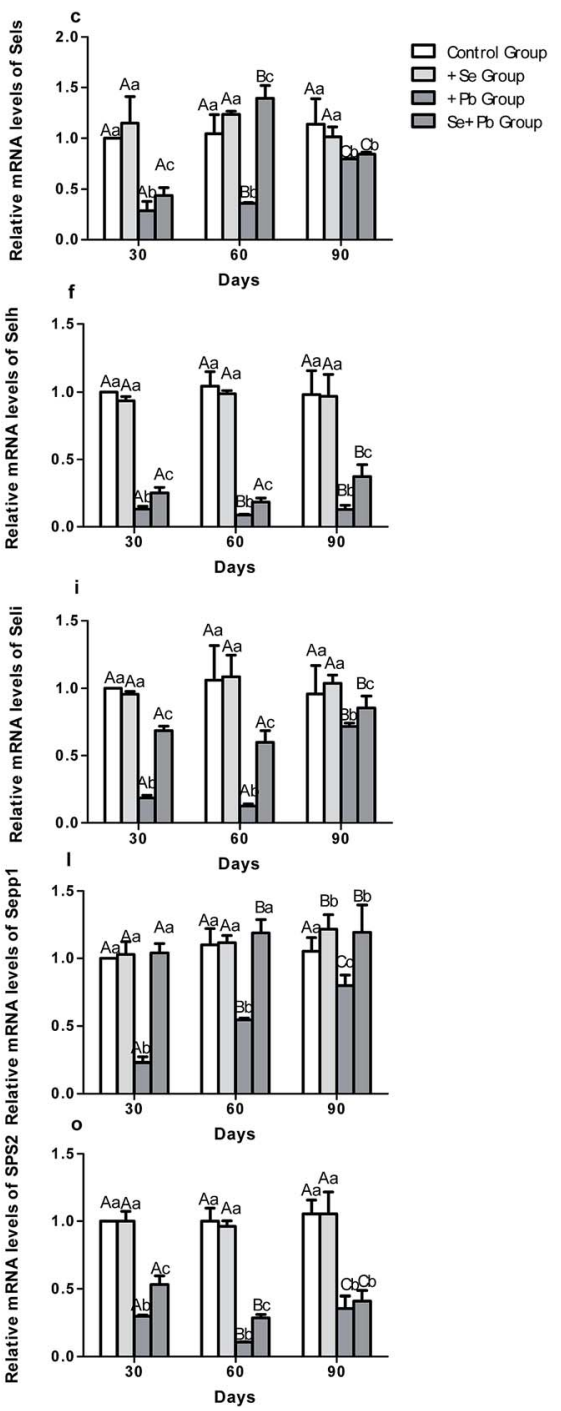

Fig. 4 Relative mRNA expression of 15 selenoproteins in chicken hearts. Fifteen chickens consisted of five replicate pens, with each pen containing three chickens. 


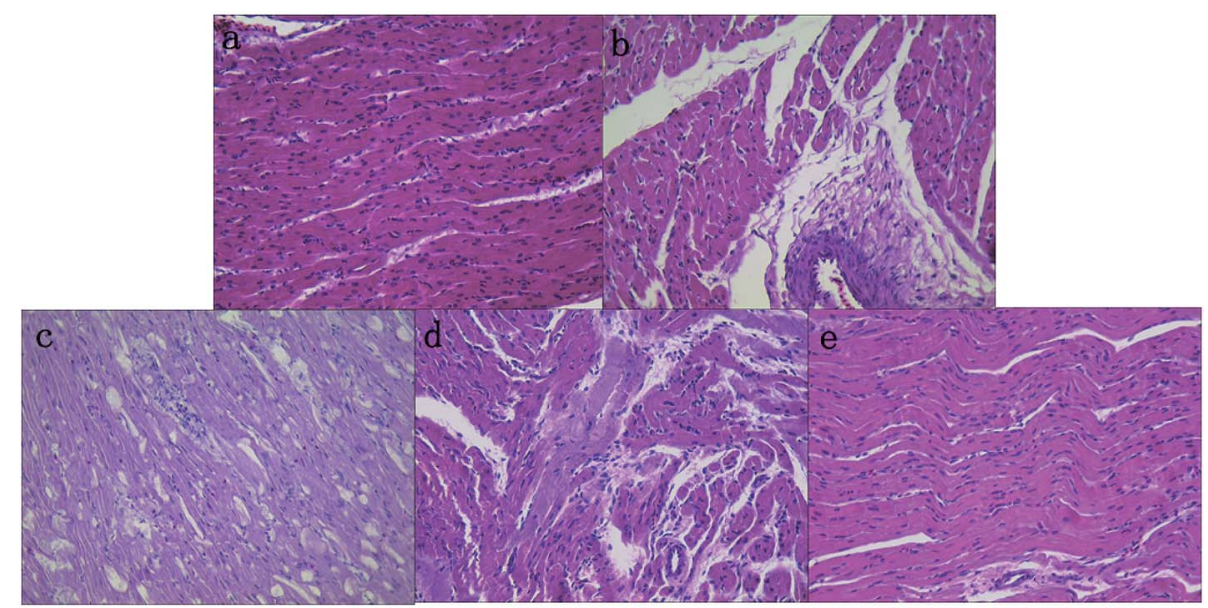

Fig. 5 Histological observations in chicken heart of dietary Se against Pb-induced inflammatory injury ( $\times 400)$. (a): The control group on the $90^{\text {th }}$ day. $(\mathrm{b}-\mathrm{d})$ : The $+\mathrm{Pb}$ group on the $30^{\text {th }}, 60^{\text {th }}$, and $90^{\text {th }}$ days. (e): The $\mathrm{Se}+\mathrm{Pb}$ group on the $90^{\text {th }}$ day.

proinflammatory cytokines in both innate and adaptive immunity. ${ }^{28} \mathrm{NF}-\kappa \mathrm{B}$ was involved in the regulation of COX-2 and TNF$\alpha$ in $\mathrm{Pb}$-induced immunotoxicity and inflammatory response. ${ }^{29}$ Excess $\mathrm{Pb}$ can induce abnormal microgliosis and astrogliosis in young mice through triggering NF-KB signaling cascades. ${ }^{30}$ Mingwei Xing et al. $^{31}$ reported that arsenic induced inflammation response and may cause chicken digestive function regression of gastrointestinal tract by affecting inflammation-related genes. Excess $\mathrm{Pb}$ increased COX-2 and PGE2 in human aorta vascular smooth muscle cells. ${ }^{32} \mathrm{~Pb}$ can cause inflammatory damage in the peripheral blood lymphocytes of chickens. ${ }^{33}$ These findings were consistent with our study. Our results indicated that excess $\mathrm{Pb}$ increased NF- $\mathrm{kB}$, PTGES, TNF- $\alpha$, and COX- 2 mRNA expression (see Fig. 1) and inflammatory injury (see Fig. 5b-d) in the chicken hearts. Our results indicated that excess $\mathrm{Pb}$ induced inflammatory injury through inhibiting NF-KB signaling pathway in the chicken hearts.

Previous studies showed that Se has antagonistic effect on toxic heavy metals. Se exerts a protective role against $\mathrm{Cd}$ induced inflammatory cytokines in chicken splenic lymphocytes $^{34}$ and $\mathrm{Pb}$-induced inflammatory cytokines in chicken peripheral blood lymphocytes. ${ }^{33}$ Our study was similar to these studies. In our study, we found that NF- $\kappa$ B, TNF- $\alpha$, COX-2, and PTGEs mRNA levels decreased in the $\mathrm{Se}+\mathrm{Pb}$ group compared to those in the $+\mathrm{Pb}$ group (see Fig. 1). Degree of inflammatory injury in the $\mathrm{Se}+\mathrm{Pb}$ group was lower than that in the $+\mathrm{Pb}$ group (see Fig. $5 \mathrm{~d}$ and e). Our results indicated that Se antagonized $\mathrm{Pb}$ induced inflammation injury in the chicken hearts.

Selenoproteins are main indicators for some functions of Se in animals. Some selenoproteins are very sensitive to dietary Se in some chicken tissues. ${ }^{35,36}$ Se deficiency caused the decline of Gpxs activity in chicken immune organs..$^{37}$ Se deficiency influenced selenoprotein gene expression in chicken muscles. ${ }^{38}$ Gpx1, Gpx2, Gpx3, Gpx4, Txnrd1, Txnrd2, Txnrd3, Dio1, Dio2, Dio3, Sepn1, Selk, Sels, Sepw1, Selt, Selh, Selm, Sep15, Seli, Selu, Selpb, Sepp1, Selo, Sepx1, SPS2 exist in chickens. These selenoproteins have anti-inflammatory properties and play important roles in inflammatory response, ${ }^{39}$ immune response, ${ }^{40}$ and apoptosis. ${ }^{41}$ One study showed that excess Pb decreased GPx in rat livers and erythrocytes. ${ }^{42}$ Our results indicated that excess $\mathrm{Pb}$ decreased mRNA levels of the 25 selenoproteins (see Fig. 2-4). Dietary Se supplementation alleviated the decrease of Gpx3, Txnrd1, Txnrd2, Txnrd3, Dio2, and Seln mRNA levels induced by aflatoxin B1 in male avian broiler livers. ${ }^{43}$ Zhao et al. ${ }^{44}$ found that Se played protective role by increasing mRNA expression of Selk, Seln, Sels, and Selt against Cd in chicken splenic lymphocytes. Gao et al. ${ }^{45}$ reported that Se alleviated the decline of selenoprotein gene expression induced by $\mathrm{Pb}$ in chicken cartilages. In accordance with the above researches, our results indicated that Se alleviated the decline of Gpx2, Gpx3, Gpx4, Txnrd1, Txnrd3, Txnrd3, Dio1, Dio3, Dio3, Sepn1, Selk, Sels, Sepw1, Selt, Selh, Selm, Sep15, Seli, Selu, Selpb, Sepp1, Selo, Sepx1, SPS2 mRNA levels induced by $\mathrm{Pb}$ in the chicken hearts.

\section{Conclusions}

In conclusions, excess $\mathrm{Pb}$ increased mRNA levels of NF- $\mathrm{kB}$, TNF$\alpha$, COX-2, and PTGEs; and decreased mRNA levels of Gpxs, Txnrds, Dios, Sepn1, Selk, Sels, Sepw1, Selt, Selh, Selm, Sep15, Seli, Selu, Selpb, Sepp1, Selo, Sepx1, and SPS2 in the chicken hearts. Excess $\mathrm{Pb}$ changed histology in the chicken hearts. Se alleviated the changes of histology and all the above inflammatory factors and selenoproteins caused by $\mathrm{Pb}$ in the chicken hearts. Se supplementation alleviated Pb-induced inflammatory injury through inhibiting NF- $\mathrm{KB}$ signaling pathway and stimulating selenoproteins in the chicken hearts.

\section{Conflict of interest}

The authors declare that there are no conflicts of interest.

\section{Acknowledgements}

The present work was support by the Agricultural Science and Technology Innovation Program (ASTIP-IAS07), and Key Special Project of National Key Research Program (2016YFD0500507)., 
the Key Laboratory of Animal Disease Control and Prevention ordinary operated by Northeast Agricultural University (No. 120105) and the Doctoral Research Foundation of Northeast Agricultural University (No. 2012RCB37).

\section{References}

1 J. Rodríguez-Estival, J. A. Barasona and R. Mateo, Environ. Pollut., 2012, 1601, 118-124.

2 J. Kasten-Jolly, H. Yong and D. A. Lawrence, J. Biochem. Mol. Toxicol., 2011, 25, 41-54.

3 S. Hou, L. Yuan, P. Jin, B. Ding, N. Qin, L. Li, X. Liu, Z. Wu, G. Zhao and Y. Deng, Theor. Biol. Med. Modell., 2013, 10, 718.

4 L. Wang, Z. Wang and J. Liu, Hum. Exp. Toxicol., 2010, 29, 581-591.

5 T. Xu, X. Gao and G. Liu, Biol. Trace Elem. Res., 2016, 169, 1-9. 6 S. Zheng, H. Song, H. Gao, C. Liu, Z. Zhang and J. Fu, Biol. Trace Elem. Res., 2016, 173, 177-184.

7 M. A. Ansari, Z. H. Maayah, S. A. Bakheet, A. O. El-Kadi and H. M. Korashy, Toxicology, 2013, 306, 40-49.

8 M. R. Simões, A. Aguado, J. Fiorim, E. A. Silveira, B. F. Azevedo, C. M. Toscano, O. Zhenyukh, A. M. Briones, M. J. Alonso and D. V. Vassallo, Toxicol. Appl. Pharmacol., 2015, 283, 127-138.

9 J. Hartupee and D. L. Mann, J. Cardiovasc. Transl. Res., 2013, 6, 485-492.

10 T. Hamid, Y. Gu, R. V. Ortines, C. Bhattacharya, G. Wang, Y. T. Xuan and S. D. Prabhu, Circulation, 2009, 119, 13861397.

11 P. R. Garg, K. N. Saraswathy, A. K. Kalla, E. Sinha and P. K. Ghosh, Gene, 2012, 514, 69-74.

12 S. Vallabhapurapu and M. Karin, Annu. Rev. Immunol., 2009, 27, 693-733.

13 V. Sreeramkumar, M. Hons, C. Punzon, J. V. Stein, D. Sancho, M. Fresno and N. Cuesta, Immunol. Cell Biol., 2016, 94, 39-51.

14 J. Y. Park, M. H. Pillinger and S. B. Abramson, Clin. Immunol., 2006, 119, 229-240.

15 N. Yazıhan, M. K. Koçak, E. Akçıl, O. Erdem, A. Sayal, C. Güven and N. Akyürek, Anadolu Kardiyol. Derg., 2011, 11, 479-484.

16 H. Y. Cogun, Ö. Fira, Ö. Fırat, T. A. Yüzereroğlu, G. Gök, F. Kargin and Y. Kötemen, J. Biochem. Mol. Toxicol., 2012, 26, 117-122.

17 Z. Zhang, M. Bi, Qi. Liu, J. Yang and S. Xu, Oncotarget, 2016, 7, 77110-77116.

18 L. V. Papp, A. Holmgren and K. K. Khanna, Antioxid. Redox Signaling, 2010, 12, 793-795.

19 L. V. Papp, J. Lu, A. Holmgren and K. K. Khanna, Antioxid. Redox Signaling, 2007, 9, 5-806.

20 M. T. Rivera, A. P. de Souza, A. H. Moreno, S. S. Xavier, J. A. Gomes, M. O. Rocha, R. Correaoliveira, J. Nève, J. Vanderpas and T. C. Araújojorge, Am. J. Trop. Med. Hyg., 2002, 66, 706-712.

21 H. Wang, S. Li and X. Teng, Biol. Trace Elem. Res., 2015, 171, 437-444.
22 V. E. Vengris and C. J. Maré, Can. J. Comp. Med., 1974, 38, 328-335.

23 C. D. Klaassen and J. B. Watkins, Casarett \& Doull's Toxicology: the Basic Science of Poisons, Mc Graw-Hill, 2013, vol. 63, p. 104.

24 M. W. Pfaffl, Nucleic Acids Res., 2001, 29, 2002-2007.

25 S. A. S. K. Barbhuiya, S. Chakraborty and M. Sengupta, Mod. Res. Inflammation, 2013, 2, 75-81.

26 A. Briasoulis, E. Androulakis, T. Christophides and D. Tousoulis, Heart Failure Rev., 2016, 21, 1-8.

27 H. J. Maier, T. G. Schips, A. Wietelmann, M. Krüger, C. Brunner, M. Sauter, K. Klingel, T. Böttger, T. Braun and T. Wirth, Proc. Natl. Acad. Sci. U. S. A., 2012, 109, 1179411799.

28 Q. T. Li and I. M. Verma, Nat. Rev. Immunol., 2002, 2, 725734.

29 C. M. Liu, Y. Z. Sun, J. M. Sun, J. Q. Ma and C. Cheng, Biochim. Biophys. Acta, Gen. Subj., 2012, 1820, 1693-1703.

30 J. T. Liu, B. Y. Chen, J. Q. Zhang, F. Kuang and L. W. Chen, Toxicol. Lett., 2015, 239, 97-107.

31 M. Xing, P. Zhao, G. Guo, Y. Guo, K. Zhang, L. Tian, Y. He, H. Chai and W. Zhang, Biol. Trace Elem. Res., 2015, 167, 1-12. 32 W. C. Chang, C. C. Chang, Y. S. Wang, Y. S. Wang, W. T. Weng, T. Yoshioka and S. H. Juo, Toxicology, 2011, 279, 45-53.

33 G. X. Sun, Y. Chen, C. P. Liu, S. Li and J. Fu, Biol. Trace Elem. Res., 2016, 172, 474-480.

34 S. Liu, F. Xu, J. Fu and S. Li, Biol. Trace Elem. Res., 2015, 168, 1-9.

35 H. D. Yao, Q. Wu, Z. W. Zhang, J. L. Zhang, S. Li, J. Q. Huang, F. Z. Ren, S. W. Xu, X. L. Wang and X. G. Lei, J. Nutr., 2013, 143, 613-619.

36 H. D. Yao, W. Liu, W. C. Zhao, R. F. Fan, X. Zhao, P. A. Khoso, Z. W. Zhang and S. W. Xu, RSC Adv., 2014, 4, 64032-64042.

37 Z. W. Zhang, Q. H. Wang, J. L. Zhang, S. Li, X. L. Wang and S. W. Xu, Biol. Trace Elem. Res., 2012, 149, 352-361.

38 H. Yao, W. Zhao, X. Zhao, R. Fan, P. A. Khoso, Z. Zhang, W. Liu and S. Xu, Biol. Trace Elem. Res., 2014, 161, 318-327.

39 S. A. Mattmiller, B. A. Carlson, J. C. Gandy and L. M. Sordillo, J. Nutr. Sci., 2014, 25, 647-654.

40 Z. H. Jiang, P. A. Khoso, H. D. Yao, Z. W. Zhang, X. Y. Zhang and S. Xu, RSC Adv., 2015, 5, 37896-37905.

41 Y. H. Han, Z. W. Zhang, J. Su, B. Zhang, S. Li and S. W. Xu, Biol. Trace Elem. Res., 2012, 147, 395-402.

42 T. O. Omobowale, A. A. Oyagbemi, A. S. Akinrinde, A. B. Saba, O. T. Daramola, B. S. Ogunpolu and J. O. Olopade, Environ. Toxicol. Pharmacol., 2014, 37, 12021211.

43 L. H. Sun, N. Y. Zhang, M. K. Zhu, L. Zhao, J. C. Zhou and D. S. Qi, J. Nutr., 2016, 146, 655-661.

44 W. Zhao, W. Liu, X. Chen, Y. Zhu, Z. Zhang, H. Yao and S. Xu, Biol. Trace Elem. Res., 2014, 161, 328-333.

45 H. Gao, C. P. Liu, S. Q. Song and J. Fu, Biol. Trace Elem. Res., 2016, 172, 234-241. 